\title{
Optimization of Grafting Season on Cleft Grafting for Deploying Commercial Propagation of Tamarind (Tamarindus indica) in Tamil Nadu
}

\author{
Mayavel A., Chitra P., Bhagatsingh C., Dharani M, Nagarajan, B.
}

Institute of Forest Genetics and Tree Breeding, Coimbatore - 641002. Tamil Nadu, India Corresponding email: mayavelscientist@gmail.com,

Received: 21 Dec 2021; Received in revised form: 09 Feb 2022; Accepted: 19 Feb 2022; Available online: 27 Feb 2022 C) 2022 The Author(s). Published by Infogain Publication. This is an open access article under the CC BY license (https://creativecommons.org/licenses/by/4.0/).

\begin{abstract}
Tamarind is one of the most important multipurpose trees grown in farm land, backyards, bund and avenues. The acidic pulp is digestive, astringent, laxative, refrigerant antiseptic and uses as main ingredient for many south Indian food preparations. Grafting is an important tool for propagation and conservation of tree genetic resources without altering genetic makeup of the species. This investigation aimed to study the effects of grafting season on the success and survivability of different Tamarind clones. Cleft grafting experiments were laid out in Completely Randomized Block Design with four replications in GTI Propagation Complex, IFGTB, Coimbatore. The Experiment comprises of 12 grafting time viz., $15^{\text {th }}$ every month from January 2019 to December 2019. Significant variations on the number of days for bud breaking, number of sprouts, number of leaves per grafts, and final survival percentage were observed on the season of grafting. The minimum number of day for bud breaking (9.25 days) was observed in the $15^{\text {th }}$ April followed by $30^{\text {th }}$ April (9.78 days)s while the maximum days for bud breaking (17.47 days) was recorded in $15^{\text {th }}$ October grafted plants. Grafting carried out on $15^{\text {th }}$ April was showed high performance in number of sprouts (8), ant height $(62 \mathrm{~cm})$ number of leaves per grafts (66.6) and final survival percentage $(85 \%)$ whereas lowest values $(35 \%)$ were recorded on $15^{\text {th }}$ October. It is concluded that the best season for clef grafting of Tamarind for deploying large scale multiplication is April to May.
\end{abstract}

Keywords-Bud breaking, Cleft grafting, Propagation, Survival, Success rate.

\section{INTRODUCTION}

Tamarind (Tamarindus indica L.) is a significant multipurpose tree belonging to the family Fabaceae (Leguminosae) with a somatic chromosome number $2 \mathrm{n}=24$ (Purseglove et al., 1987). The species is widely distributed in Bangladesh, Sri Lanka, Myanmar, Australia, Malaysia, Thailand and also in African, South American and North American continents (Mishra, 1997). It has been naturalized in the southern part (Andhra Pradesh, Madhya Pradesh, Karnataka and Tamil Nadu) of India where moist deciduous and tropical evergreen forests are commonly found (Champion and Seth, 1968). India is the largest producer of Tamarind in the globe with the production of 2, 27,000 tonnes during the year 2017-2018 (Horticulture statistics, 2018).The acidic pulp is digestive, astringent, laxative, refrigerant, antiseptic and used as a main ingredient for many south Indian food preparations.

Tamarind fruit pulp is used for cooking in many south Indian preparations. It is also used in nutrition of sauces, marinades, chutneys, drinks and desserts. The beverages prepared from tamarind fruit pulp is commonly used to treat constipation, diarrhoea, fever and ulcers. Tamarind is generally propagated through seeds and grafting. The seed propagation results in segregation in the progenies and creates huge variability in the plantations. The tamarind plantation established with seedlings will not have true to type progenies and have long juvenile period. Further, it greatly challenges to maintain the purity of the 
variety. The clonal propagation of tamarind will produce true to type, dwarf plants. Different methods of clonal propagation such as rooting of cuttings, air layering, cutting and grafting were attempted for mass multiplication. Approach and cleft grafting are the most common methods adopted for large scale multiplication of tamarind. The approach method needs special platform for grafting and maintenance of grafts in the field is very difficult. The cleft grafting is the common and easiest method which is used for large scale multiplication of tamarind phenotypes. The success, growth, development and survivability of tamarind grafts are controlled by several factors, among which time of grafting plays a crucial role in the success and survivability of grafts (Hartmann et al., 2002, Kumar, 2011). With this background, the present experiment was attempted to study the effect of time of grafting on the success and survivability in tamarind. The main objective of the experiment was to find out the appropriate time of cleft grafting for higher percentage of grafts success and survival.

\section{MATERIALS AND METHODS}

The study was carried out in the Grafting chamber of Institute of Forest Genetics and Tree Breeding, Coimbatore from January 2019 to December 2019 to standardize the season of grafting for large scale multiplication of tamarind. The study area is located at $11^{\circ} 018^{\prime} .77^{\prime \prime} \mathrm{N}, 76^{\circ} 94^{\prime} .71^{\prime \prime E}$ Eonan elevation of $312 \mathrm{~m}$ AMSL. The soil is dominated with black cotton soil with low fertility. The area receives an annual rainfall of 750 $\mathrm{mm}$ from the rains of both South West and North-East monsoons and the temperature varied from $23^{\circ} \mathrm{C}$ to $35^{\circ} \mathrm{C}$. The experiment was laid out in completely randomized design (CRD) with 12 treatments and four replications. Each replication consisted of 30 grafts. The details of treatments are T1- mid of January, T2- mid of February, T3- mid of March, T4- mid of April, T5- mid of May, T6 mid of June, T7- mid of July, T8- mid of August, T9- mid of September, T10- mid of October, T11- mid of November, T12- mid of December. Six months old tamarind seedlings of pencil size thickness, vigorous growth, and uniform size were selected as rootstock for grafting. The selected scion sticks were defoliated a week prior to grafting. The scions were collected from the selected mother tree in the early morning $(7-10 \mathrm{am})$ on the day of grafting. Scion materials were wrapped in moist gunny bag after removal from the mother plant and were transported to the grafting chamber. The scion shoots were disinfected in $0.2 \%$ Bavistin solution to obtain pathogen free shoots. Grafting was done on the same day of separation of scion from the mother plant. The rootstock seedlings are defoliated and their tops cut off at $15 \mathrm{~cm}$ high immediately before grafting. A vertical downward cut is made in the center of the root stock at $4 \mathrm{~cm}$ depth and the scion sticks are cut into wedge shapes, inserted into the stock and wrapped using $2 \mathrm{~cm}$ wide 200 gauge polyethylene strips. These were wrapped in a moist cloth and carried in polythene covers to the site of grafting. Cleft grafting was performed and the scions were covered with small polythene caps to avoid desiccation of the scion by creating humidity near and above the graft union. The observation on the graft success was recorded at 45 days after grafting and graft survival and growth parameters like percentage of survival, the height of rootstock, height of scion and number of leaves were recorded at 90 days after planting. One - way analysis of variance was conducted to test the significance of results and Duncan's test was conducted to compare the means of treatment.

\section{RESULTS AND DISCUSSION}

The effect of season of grafting on the success and survival percentage of grafting are presented in Table 1. The time of grafting has recorded significant differences in days required for bud breaking $(\mathrm{F}=2.67, \mathrm{p}=0.01)$, girth of root stock $(F=2.79, p=0.01)$, girth of scion $(F=$ $3.88, p=0.01)$, length of root stock $(F=6.56, p=0.01)$, length of scion $(\mathrm{F}=3.85, \mathrm{p}=0.01)$, plant height $(\mathrm{F}=3.76$, $\mathrm{p}=0.01)$, success percentage $(\mathrm{F}=12.60, \mathrm{p}=0.01)$ and survival percentage $(\mathrm{F}=15.34, \mathrm{p}=0.01)$. The plants grafted in April recorded the minimum days (9.78) towards bud breaking whereas those grafted in October required the maximum number of days (17.47) for bud breaking. This can be attributed to the mobility of reserved food material within the scion and congenial environmental condition during grafting. Similar results were recorded by Sivudu et al., (2014) in mango and Giri and Lenka (2007) in jamun. 
Table 1: Effect of grafting time on the growth and development of Tamarind

\begin{tabular}{|c|c|c|c|c|c|c|c|c|c|c|}
\hline Months & $\begin{array}{l}\text { Days } \\
\text { required } \\
\text { for bud } \\
\text { breaking }\end{array}$ & $\begin{array}{l}\text { Success } \\
\text { Percentage } \\
(\%)\end{array}$ & $\begin{array}{l}\text { No. of } \\
\text { sprouts }\end{array}$ & $\begin{array}{l}\text { Length } \\
\text { of Root } \\
\text { Stock } \\
(\mathrm{cm})\end{array}$ & $\begin{array}{l}\text { Length } \\
\text { of Scion } \\
(\mathrm{cm})\end{array}$ & $\begin{array}{l}\text { Girth of } \\
\text { Root } \\
\text { Stock } \\
(\mathrm{cm})\end{array}$ & $\begin{array}{l}\text { Girth of } \\
\text { Scion } \\
(\mathrm{cm})\end{array}$ & $\begin{array}{l}\text { Plant } \\
\text { Height } \\
(\mathrm{cm})\end{array}$ & $\begin{array}{l}\text { Leaf } \\
\text { Number }\end{array}$ & $\begin{array}{l}\text { Survival } \\
\text { Percentage } \\
(\%)\end{array}$ \\
\hline January & $12.8^{\mathrm{bc}}$ & $70.1^{\mathrm{c}}$ & $4.7^{\mathrm{bc}}$ & $19.21^{\mathrm{bc}}$ & $26.8^{\mathrm{bc}}$ & $0.50^{\mathrm{cd}}$ & $0.49^{\mathrm{b}}$ & $46.01^{\mathrm{cd}}$ & $33.4^{\mathrm{ef}}$ & $63.2^{\mathrm{d}}$ \\
\hline February & $14.6^{\mathrm{c}}$ & $84.3^{\mathrm{b}}$ & $4.2^{\mathrm{bc}}$ & $20.46^{\mathrm{b}}$ & $29.14^{\mathrm{b}}$ & $0.55^{\mathrm{bc}}$ & $0.48^{\mathrm{bc}}$ & $49.60^{c}$ & $40.6^{\mathrm{de}}$ & $75.6^{\mathrm{bc}}$ \\
\hline March & $10.76^{\mathrm{b}}$ & $90.6^{\mathrm{ab}}$ & $6.7^{\mathrm{b}}$ & $22.68^{\mathrm{ab}}$ & $33.12^{\mathrm{a}}$ & $0.65^{\mathrm{b}}$ & $0.50^{\mathrm{b}}$ & $55.80^{\mathrm{b}}$ & $62.1^{\mathrm{ab}}$ & $81.9^{\mathrm{b}}$ \\
\hline April & $9.78^{\mathrm{a}}$ & $95.5^{\mathrm{a}}$ & $8.2^{\mathrm{a}}$ & $27.46^{\mathrm{a}}$ & $34.6^{\mathrm{a}}$ & $0.71^{\mathrm{a}}$ & $0.53^{\mathrm{a}}$ & $62.6^{\mathrm{a}}$ & $66.6^{\mathrm{a}}$ & $85.3^{\mathrm{a}}$ \\
\hline May & $10.98^{b}$ & $92^{\mathrm{ab}}$ & $7.5^{\mathrm{ab}}$ & $21.46^{\mathrm{ab}}$ & $29.78^{\mathrm{b}}$ & $0.60^{\mathrm{b}}$ & $0.44^{\mathrm{c}}$ & $51.24^{\mathrm{b}}$ & $37.4^{\mathrm{e}}$ & $81.2^{\mathrm{b}}$ \\
\hline June & $12.44^{\mathrm{bc}}$ & $82.2^{\mathrm{b}}$ & $6.3^{\mathrm{b}}$ & $22.2^{\mathrm{ab}}$ & $30.37^{\mathrm{b}}$ & $0.59^{\mathrm{b}}$ & $0.42^{\text {cd }}$ & $52.57^{\mathrm{b}}$ & $31.8^{\mathrm{f}}$ & $76.9^{\mathrm{bc}}$ \\
\hline July & $16.78^{\mathrm{cd}}$ & $78.5^{\mathrm{bc}}$ & $5.8^{\mathrm{b}}$ & $20.58^{\mathrm{b}}$ & $27.76^{\mathrm{bc}}$ & $0.58^{\mathrm{b}}$ & $0.41^{\mathrm{d}}$ & $48.34^{\mathrm{c}}$ & $47.6^{\mathrm{d}}$ & $68.1^{\mathrm{d}}$ \\
\hline August & $15.84^{\mathrm{cd}}$ & $74.7^{\mathrm{c}}$ & $3.3^{\mathrm{c}}$ & $22.78^{\mathrm{ab}}$ & $29.64^{\mathrm{b}}$ & $0.58^{\mathrm{b}}$ & $0.41^{\mathrm{d}}$ & $52.42^{\mathrm{b}}$ & $54.2^{\mathrm{c}}$ & $55.7^{\mathrm{e}}$ \\
\hline September & $15.67^{\mathrm{cd}}$ & $67.2^{\mathrm{cd}}$ & $3.7^{\mathrm{c}}$ & $17.56^{\mathrm{c}}$ & $28.24^{\mathrm{bc}}$ & $0.53^{\mathrm{bc}}$ & $0.44^{\mathrm{c}}$ & $45.80^{\text {cd }}$ & $47.8^{\mathrm{d}}$ & $54.2^{\mathrm{e}}$ \\
\hline October & $17.47^{\mathrm{d}}$ & $50.8^{\mathrm{d}}$ & $2.4^{\mathrm{c}}$ & $16.86^{\mathrm{d}}$ & $25.54^{\mathrm{d}}$ & $0.49^{\mathrm{d}}$ & $0.40^{\mathrm{e}}$ & $42.4^{\mathrm{d}}$ & $20.6^{\mathrm{g}}$ & $35.9^{\mathrm{g}}$ \\
\hline November & $14.76^{\mathrm{c}}$ & $55.2^{\mathrm{d}}$ & $1.6^{\mathrm{d}}$ & $17.14^{\mathrm{c}}$ & $29.82^{b}$ & $0.51^{\text {cd }}$ & $0.41^{\mathrm{d}}$ & $46.96^{\mathrm{cd}}$ & $33.2^{\mathrm{ef}}$ & $44.1^{\mathrm{f}}$ \\
\hline December & $13.67^{\mathrm{c}}$ & $63.1^{\mathrm{cd}}$ & $2.3^{\mathrm{d}}$ & $16.23^{\mathrm{d}}$ & $25.34^{c}$ & $0.50^{\text {cd }}$ & $0.45^{\mathrm{c}}$ & $41.53^{\mathrm{d}}$ & $59.4^{\mathrm{bc}}$ & $52.3^{\mathrm{e}}$ \\
\hline
\end{tabular}

Values with similar superscripts are homogenous.

The maximum number of sprouts (8.2) was obtained during April and the minimum number of sprouts (1.6) was obtained during November. Similar findings were reported by Dhutraj et al., (2018) in tamarind. The maximum number of sprouts might probably be due to the presence of more active buds and stored food materials in the scion attributed better healing of the graft union. However, the minimum number of sprouts in November might be due to lower temperatures during this month and poor sap flow in the grafts plants. Similar findings were reported by Ghojage et al., (2011) in Jamun, Pawar et al., (2003), and Kudmulwar et al., (2008) in custard apple. The grafts produced during April exhibited the highest root stock length $(27.4 \mathrm{~cm})$ and those of October recorded the lowest length $(16.86 \mathrm{~cm})$ of root stock. On the other hand, the plants grafted during April have produced the longest scions $(34.6 \mathrm{~cm})$ while those of October produced the shortest scions $(25.34 \mathrm{~cm})$. The minimum value of girth of root stock $(0.49 \mathrm{~cm})$ and scion $(0.0 \mathrm{~cm})$ was recorded during October whereas the maximum value of girth of root stock $(0.71 \mathrm{~mm})$ and scion $(0.53 \mathrm{~mm})$ was recorded during April. The higher growth of stock and scion might be due to the presence of endogenous gibberellin levels in the grafts and it stimulates more cell division and cell enlargement. The results of the present study are in conformation with findings of Chovatia and Singh (2000) and Bharad et al., (2006) in Jamun. The maximum stock and scion thickness in cleft grafted plants are in contradiction with the findings of Somkumar et al., (2009) stating that cleft grafting during 15th August in grape cv. TasA-Ganesh as scion resulted in the thickest shoot and Somkumar et al., (2009) reported that cleft grafting during 15th August in grape cv. TasA-Ganesh as scion resulted in the thickest shoot.

The tallest plants $(62.6 \mathrm{~cm})$ were obtained from grafts produced during April probably due to proper intermingling and interlocking of stock and scion to create proper union and quick healing of joint. Meanwhile, shortest plants $(41.53 \mathrm{~cm})$ were obtained during December. Lower length of scion and stock of grafted plants might be due to relatively lower temperature during this month which makes bud to be in dormant stage and poor sap flow in the grafts. Similar findings were reported by Ghojage et al., (2011) in jamun, Pawar et al., (2003) and Kudmulwar et al., (2008) in custard apple. The leaf number was highest (66.6) in grafts produced during April and recorded the lowest (20.6) in grafts produced during October. Better growth of grafts during April could also be correlated to higher cell activity and active growth of both stock and scion in the prevailing favourable climatic condition. Pawar et al., (2003) in custard apple and Ghojage et al., (2011) in jamun recorded similar results. 


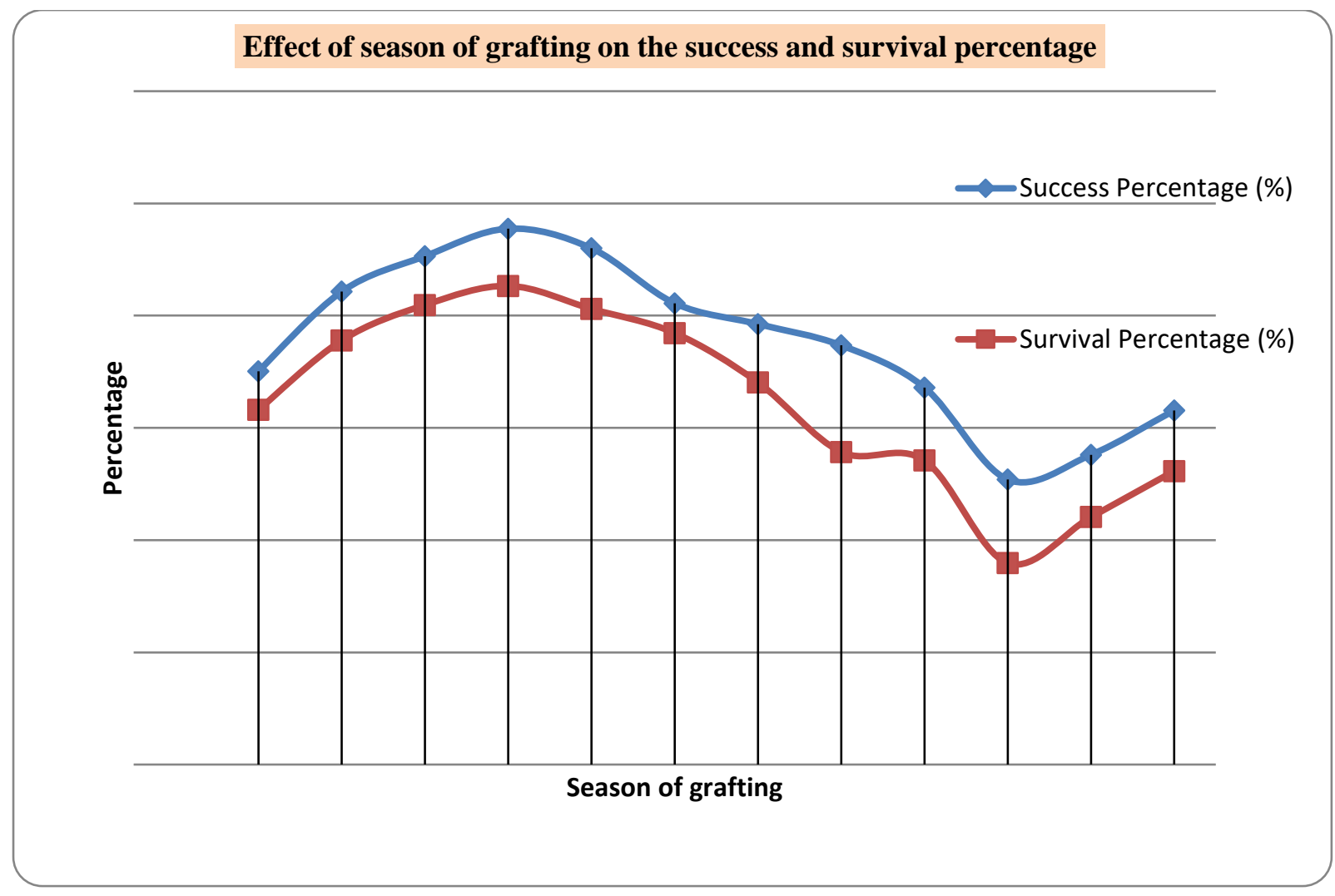

Fig.1. Effect of grafting on the success and survival percentage of tamarind grafts

The success percentage and survival percentage of grafts also followed a similar trend with the highest percentage in April (95.5\% and $85.3 \%$ respectively) and the lowest percentage in October $(50.8 \%$ and $35.9 \%$ respectively). Higher grafting success during the month of April and May was mainly because of high humidity and temperature resulting in optimum cambial activity in both stock and scion. The active physiological state of the scion supports for better sap flow at that time of graft union formation and it attributes proper intermingling and interlocking of stock and scion to form proper graft union. The lowest grafting success and survival were recorded during the rainy season due to low temperature and humidity leading to poor sap flow. In addition, the plants tend to invest the energy present in the scion materials towards fruit production. The present finding is in lieu with the findings of Sulikeri et al., (1997) stating that the months of April and May were best suited for soft grafting in sapota with graft success of 47 to $62 \%$. It was evident that the performance of plants grafted during March, April (highest) and May were superior over other months (Figure 1). It is stated that the rate of graft union increases linearly with temperature between $5{ }^{\circ} \mathrm{C}$ and $32^{\circ} \mathrm{C}$ (Sadhu, 2005). The present study was in confirmation with the above statement where in the average temperature of the study area was $30{ }^{\circ} \mathrm{C}$ during April. In addition the photosynthetic activity of and callus formation in the grafts are influenced by the availability of light (Afshari et al., 2011) which further added to the success of grafts during April. Increased light availability is believed to increase nutrient accumulation due to photosynthesis enhancing the graft union formation (Islam et al., 2004). Thus the higher success of grafted plantlets in April can be attributed to the longer light period received by the plantlets. Therefore the propagation of Tamarind using cleft grafting technique during the month of April can be recommended for the study area and areas with similar agro-ecologies to deploying large scale multiplication of Tamarind.

\section{CONCLUSION}

The study aimed at understanding the effect of grafting time on the success and survival percentage of grafts to deploy large scale production of grafts. It was found that those plants grafted during the months of April and May was superior in quality over the other seasons. Hence it can be concluded that large scale multiplication of tamarind through cleft grafting can be successfully achieved by practicing the grafting in the months of April and May. 


\section{ACKNOWLEDGMENT}

The authors acknowledge the Indian Council of Forestry Research and Education (ICFRE), Director (IFGTB) and Compensatory Afforestation Fund Management and Planting Authority (CAMPA) for financially supporting the study.

\section{REFERENCES}

[1] Afshari, R.T., Angoshtari, R. and Kalantari, S. 2011. Effect of light and different plant growth regulators on inductions of callus growth in repeseed (Brassica napus) genotype. J. Plant Mol. Biol. Omics 4:60-67.

[2] Bharad, S. G., Rajput, L., Gonge, V. S. and Dalal, S. R. 2006. Studies on time and method of vegetative propagation in Jamun. Proceedings of the national symposium on production, utilization and export of underutilized fruits with commercial potentialities, Kalyani, Nadia, West Bengal, India, 22-24 November, 2006: pp 96- 99.

[3] Chovatia, R. S. and Singh, S. P. 2000. Effect of time on budding and grafting success in Jamun (Syzygium cumini Skeels.) Ind. J. Hortic. 57(3):255-58.

[4] Dhutraj, S. V., Deshmukh, R.V. and Bhagat, V. V. 2018.Standardization of period for softwood grafting in tamarind (Tamarindus indica L.). J. Pharmacogn. and Phytochem. 7(5): $439-441$.

[5] Gadekar, S. G., Bharad, V. P. and Patil, S. 2010. Seasonal variation in success of softwood grafting of jamun under Akola conditions. Asian. J. Hortic. 2 : 266-268.

[6] Ghojage, A. H., Swamy, G. S., Kanamadi, V. C., Jagdeesh, R. C., Kumar, P.,Patil, C. P. and Reddy, B. S. 2011. Effect of season on softwood grafting in jamun (Syzygium cumini Skeels.). Acta Hortic. 890: 123-27.

[7] Giri, B. and Lenka, P. C. 2007.Effect of time on grafting success in jamun (Syzygium cumini). Orissa J. Hortic. 35 : 122-23.

[8] Hartmann, H.T., Kester, D.E., Davies, F.T., and Geneve, R.L. 2002. Hartmann and Kester's plant propagation: Principles and practices. 8th ed. Prentice Hall, Upper Saddle River, New Jersey, USA.

[9] Islam, M. R. and Rahim, M. A. 2010.Performance of epicotyl grafting in different varieties of mango. J. Agrofor. Environ. $4: 45-50$.

[10] Islam, M.N., Rahim, M.A., Naher, M.N.A., Azad, M.I., and Shafjahan, M. 2004. Effect of time of operation and age of rootstock on the success of inserted contact grafting in mango. Asian J. Plant Sci. 3(5):636-641.

[11] Kudmulwar, R. R., Kulkarni, R., Katkar, P. B. and Dugmod, S. P. 2008. Standardization of softwood grafting season on success of custard apple (Annona squamosa L.). Asian J. Hortic. 3 : 281-82.

[12] Kumar, G.N.M. 2011.Propagation of plants by grafting and budding. A Pacific Northwest Extension Publication, Pullman, Washington, USA. 16p.

[13] Pawar, D. M., Ingle, V. G. and Panchabhai, D. M. 2003. Effect of age of rootstock and time of grafting on success of soft wood grafts of custard apple under local conditions. Ann. Plant Physiol. 17 : 53-55.

[14] Sadhu, M.K. 2005. Plant propagation. New Age International Ltd., New Delhi, India. 296p.

[15] Sivudu, B. V., Reddy, M. L. N., Baburatan, P. and Dorajeerao, A.V. D. 2014. Effect of structural conditions on veneer grafting success and survival of mango grafts (Mangifera indica cv. Banganpalli). Plant. Arch. 14 : 71-75.

[16] Somkumar, R. G., Satisha, J. and Ramteke, S. D. 2009. Propagation success in relation to time of grafting in Tas-AGanesh grapes. J. Maharashtra Agri. Uni. 34: 113-14

[17] Sulikeri, G.S., Patil V.S., Madalgeri M.B. and Mokashi, A.N. 1997. Standardization of softwood grafting technique in sapota. In. Research and Development in Fruit Crops in North Karnataka, University of Agricultural Sciences, Dharwad, 40-42. 